\title{
HIGHLIGHTS OF SOME HUMAN ADVENTURES IN A KARST ENVIRONMENT: THE CASE OF THE MONTI LESSINI, VENETIAN PREALPS, ITALY
}

\author{
ČLOVEK IN KRAS: PRIMER LESINSKIH ALP, BENEŠKE \\ PREDALPE, ITALIJA
}

Ugo SAURO $^{1}$

\begin{abstract}
UDC 551.435.8:930.85(450.32/.34)

Ugo Sauro: Highlights of some human adventures in a karst environment: the case of the Monti Lessini, Venetian Prealps, Italy

The Monti Lessini, a mountain group located north of the town of Verona, has been the scene of many different human adventures, some of them related to the local karst environment and features. In particular, during the Late Middle Ages, the Renaissance and the Modern Age, interesting undertakings linked with natural monuments and peculiarities of the karst environment, have involved famous people, cultural leaders of the time, as well as local inhabitants. Amongst celebrities there are hints that: 1) during the XIV. century Dante Alighieri visited some karst cavities in the mountains, 2) during the XV. century the famous painter Andrea Mantegna painted an image of the Ponte di Veja, a natural bridge, in the Camera degli Sposi of the Ducal Palace of Mantua. Of contemporary cultural leaders: 1) in the XVI. century the pharmacist, Francesco Calceolari, created one of the first Wunderkammer in the world in Verona, an exhibition of curious objects collected in the mountains, 2) in 1739 the local priest, Gregorio Piccoli, starting from a description of paleontological cave fillings, proposed an interesting and in some respects modern interpretation of the geological history of the mountains. The local inhabitants of the mountain have been able not only to solve some of the environmental problems caused by the scarcity of surface water, but also to exploit some of the unusual resources such as ice trapped in caves. They also developed a system of producing ice and of storing it in cylindrical warehouses inspired by the local karst shafts. They understood aspects of the functioning of the karst geosystem, including underground karst hydrology and the dynamics of the epikarstic zone. Thus, here in the Lessini existence of the epikarst was understood by simple people long before the modern researchers.

Key words: man and karst, understanding of the karst environment, exploitation of natural resources, Monti Lessini, Venetian Prealps, Italy.
\end{abstract}

Izvleček UDK 551.435.8:930.85(450.32/.34)
Ugo Sauro: Človek in kras: primer Lesinskih Alp, Beneške
predalpe, Italija V Lesinskih Alpah, gorski skupini severno od Verone, so se dogajale številne zanimive zgodbe, med njimi tudi takšne, ki so neposredno povezane $s$ krasom in kraškimi pojavi. $\mathrm{V}$ poznem srednjem veku, renesansi in moderni dobi, se z lesinskim krasom srečajo številne zgodovinske osebnosti iz kulturnega življenja in drugih okolij. V XIV. stoletju naj bi tu nekatere jame obiskal Dante Alighieri, slikar Andrea Mantegna je narisal naravni most Ponte di Veja, slika danes krasi poročno dvorano Vojvodske palače v Mantovi. V XVI. stoletju je farmacevt Francesco Calceolari ustvaril prvo sobo čudes (Wunderkammer) na svetu, kjer je predstavil nenavadne predmete iz Lesinskih Alp. Leta 1739 je duhovnik Gregorio Piccoli opisal paleontologijo jamskih sedimentov iz lesinkih jam in predstavil skoraj moderno interpretacijo geološke zgodovine gorovja. Krajevni prebivalci so na izvirne načine reševali težave $\mathrm{z}$ oskrbo vode na krasu, po drugi strani pa so s pridom izkoristili naravne vire, ki jih nudi kras, npr. jamski led. Po vzoru kraaških brezen so izdelovali tudi skladišča za led. Prebivalci so razumeli osnovna načela delovanja kraškega okolja, podzemne hidrologije in dinamike epikrasa ter jih izkoriščali v svoj prid že veliko pred razvojem modernega krasoslovja.

Ključne besede: človek in kras, razumevanje kraškega okolja, izkoriščanje naravnih virov, Lesinske Alpe, Beneške predalpe, Italija.

\footnotetext{
${ }^{1}$ Museum of Man and the Environment in the Monti Lessini - Bosco Chiesanuova, Verona, Italy, e-mail: ugo.sauro@gmail.com Received/Prejeto: 31.08 .2016
} 


\section{INTRODUCTION}

The Monti Lessini, also called "Lessinia", is a mountain group located north of the town of Verona in the Venetian Prealps belt.

The plateau is mainly composed of carbonate rocks of Mesozoic age. Tectonic structural and fluvial morphology prevail on the surface. The relief range is of about $1800 \mathrm{~m}$ (from the $50 \mathrm{~m}$ a.s.l. of the high venetian plain to $1865 \mathrm{~m}$ of the highest peak). There are numerous natural monumental features and about 1000 karstic cavities have been registered and mapped. The most famous is the Spluga della Preta, which was considered for about 30 years (1920s to 1950s) the deepest known karst cavity in the world. Since prehistoric times this mountainous environment has been the scene of many different human undertakings and adventures, some of them closely related to local karst conditions and landscape, helping us to understand the evolution of the relationships between man and this mountainous area (Sauro 1973, 2010) (Fig. 1).

There are three main reasons why the Lessini Mountains have been a special environmental laboratory for humans:

1) - the presence of abundant and good quality chert,
2) - the relationship with the town of Verona, which was founded at the foot of the mountains,

3) - the settlement in the Late Middle Ages of human groups coming from Bavaria and the Tyrol.

Here we dwell mainly on points 2) and 3), with particular reference to the relationship between man and the karst environment.

The presence of good quality chert favoured the settlement of prehistoric people, who have left stone tools since the lower Palaeolithic. Among other items, 'Oetzi', the Neolithic Ice Age man of Similaun (the body of a man of about 5300 years BP, found frozen with his clothes and arms in the Atesine Alps at over $3000 \mathrm{~m}$ of altitude) carried chert tools from Lessini with him. In our modern age, Lessinia has been one of the main sources of flints in Europe.

From the Middle Ages to modern times the proximity of Verona to the mountains has attracted contemporary leaders of the culture of the time. In particular, during the late middle ages, the Renaissance and our modern age, international celebrities, cultural leaders and local inhabitants have all interacted with and enjoyed the natural monuments and peculiar features of the karst environment.

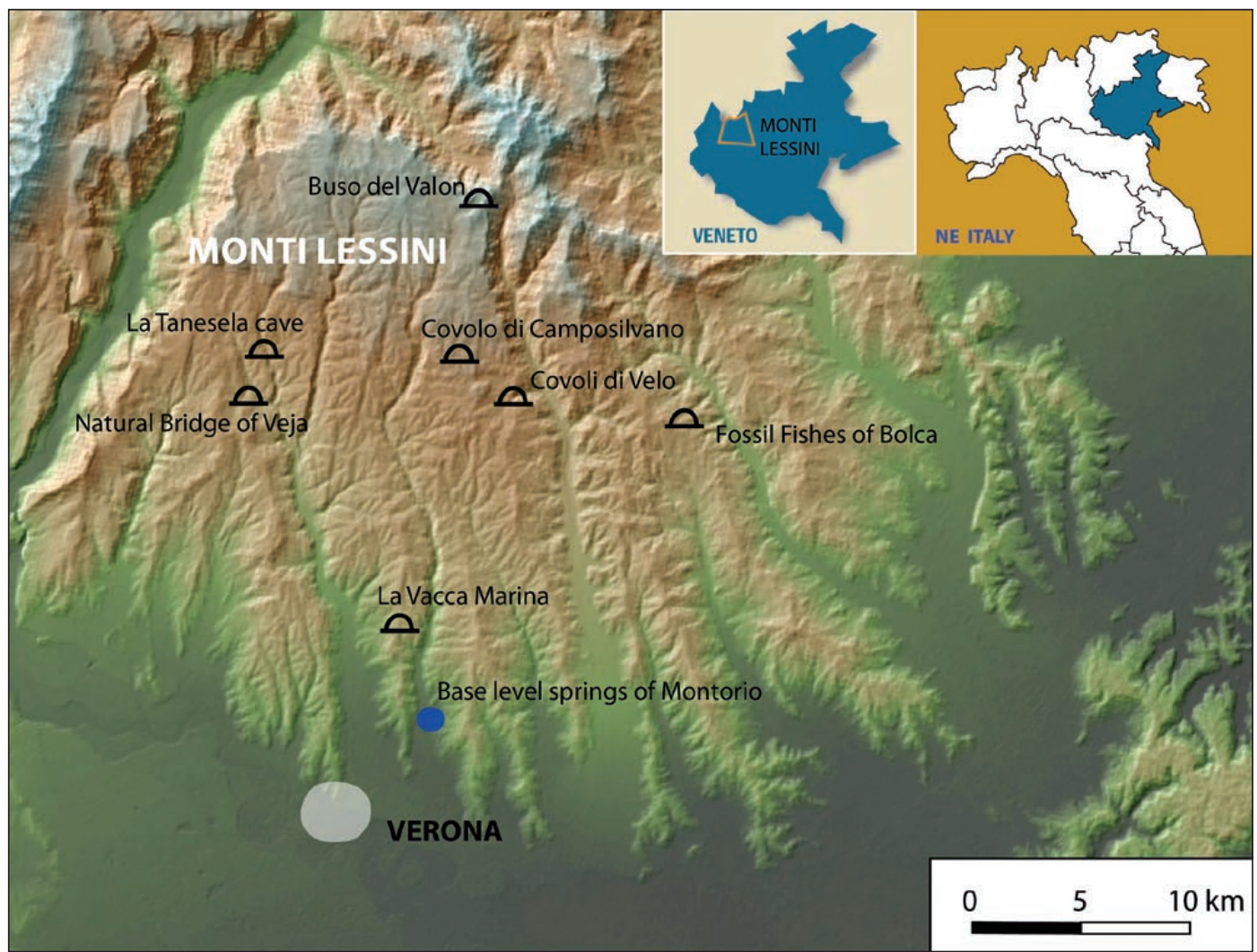

Fig. 1: Geographical digital elevation map of the Lessini Mountains, showing the locations of the main natural monuments and paleontological sites mentioned in the text. 


\section{THE KARST AND SOME CELEBRITIES}

\section{DANTE ALIGHIERI}

Dante Alighieri lived in Verona for over six years between 1312 and 1318. In his "Comedy" we find clues that he visited some of the karst in the Lessini Mountains. He was a guest of the Della Scala family, the chief rulers of Verona at the time. These lords had properties in Monti Lessini where they hunted bears and deer; Dante certainly participated in the hunting (Benetti \& Ragnolini 2008). At that time, in the village of Camposilvano, new settlers of German (Bavarian) origin called "Cimbri" were engaged in cutting down a great forest of beech trees (hence the name, "Campo" = field, and Silvano - from the Latin "Silva" = in the forest). There is a surviving oral tradition that Dante visited the spectacular collapsed doline, the 'Covolo di Camposilvano', a large, nearly cylindrical cavity that leads into the remains of a great cave chamber (Fig. 2), at the bottom of which, in the recent past (up to the 60s of the last century), ice could be observed even during the summer season. Therefore, the cavity was used as a natural refrigerator from proto-historic times. According to local tradition Dante was inspired by this cavity in defining his model of Hell in the "Divine Comedy", at the bottom of which he placed a lake of ice.

In the Comedy, several verses describing the visit to Hell show similarities with a visit to this cave, suggesting that Dante really went down into the chasm:

valle d'abisso dolorosa... (Inferno $I V, 8$ )

oscura e profonda era e nebulosa,

tanto che,... io non vi discernea alcuna cosa.

Ora discendiam qua giù nel cieco mondo.

(Inferno IV, 10-13)

Luogo è in inferno detto Malebolge

tutto di pietra di color ferrigno,

come la cerchia che d'intorno il volge

Nel dritto mezzo del campo maligno

vaneggia un pozzo assai largo e profondo ...

(Inferno XVIII, 1-5)

Per ch'io mi volsi e vidimi davante

e sotto i piedi un lago che per gelo

avea di vetro e non d'acqua sembiante.

(Inferno, XXXII, 22-24)

Thus, to a visitor of the Covolo of Camposilvano the remains of the collapsed chamber appears dark and deep and often contain a nebula (cloud) of mist that forms during the day due to the evaporation of water and its condensation on the colder roof of the cavity: oscura $e$ profonda era e nebulosa (was dark, deep and nebulous); the collapsed doline is a nearly circular depression: la cerchia che d'intorno il volge (the circular pattern of rock walls in the collapse pit overlooking the deep residual chamber); the rock walls are composed of pietra di color ferrigno (a rusty coloured stone due to the reddish color of iron oxide contained in the Rosso Ammonitico formation, which makes up part of the roof of the large chamber and the walls of the collapse cavity). Probably the collapse of large blocks was triggered by the famous Verona earthquake of $1117 \mathrm{AD}$, creating large, fresh niches in the walls in which the bright red coloration of the unweathered rock will have emphasized; and as we have seen, ice that is mostly derived from the freezing of dripping water and of some small seeps, can be found at the bottom of the deeper cavity, forming a lago che per gelo avea di vetro e non d'acqua sembiante (lake that looks like glass rather than water) (Fig. 3).

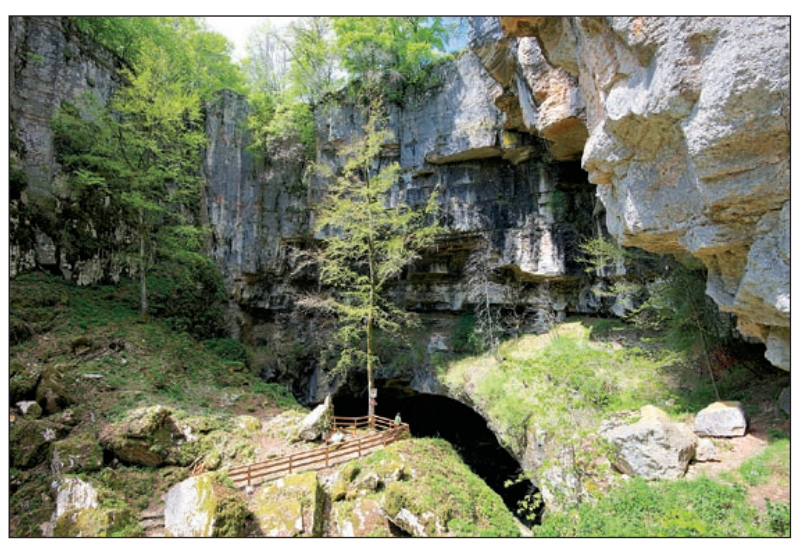

Fig. 2: Detail of the wall system of the collapse doline called the Covolo of Camposilvano. Below we can see the dark entrance to the residual part of the partly collapsed underground chamber. On some spots of the walls, where the biological patina is not well developed, it is possible to see the reddish color of the rock that belongs to the formation Rosso Ammonite Veronese (photo: U. Sauro).

From oral tradition, it is also known that on the lintel of the door in the artificial wall that controlled access to the cavity was carved the famous verse of the Commedia: Lassate ogni speranza voi che entrate (Abandon all hope ye who enter here).

Some authors have written that Dante Alighieri would have also visited two other karst features: the Ponte di Veja and the Buso del Valon. With reference to the latter cavity, a document of $1349 \mathrm{AD}$ informs us that the Lords della Scala required the settlers named "Cimbri" to provide ice to their home during the summer. The only cavity in which there is a relatively large glacière is the Buso del Valon del Malera (Sauro 2010). Close to this great karst well the remains of a late-medieval village in the form of the stone bases of wooden houses have been found, which might have hosted the team of ice miners (Sauro et al. 2013). 


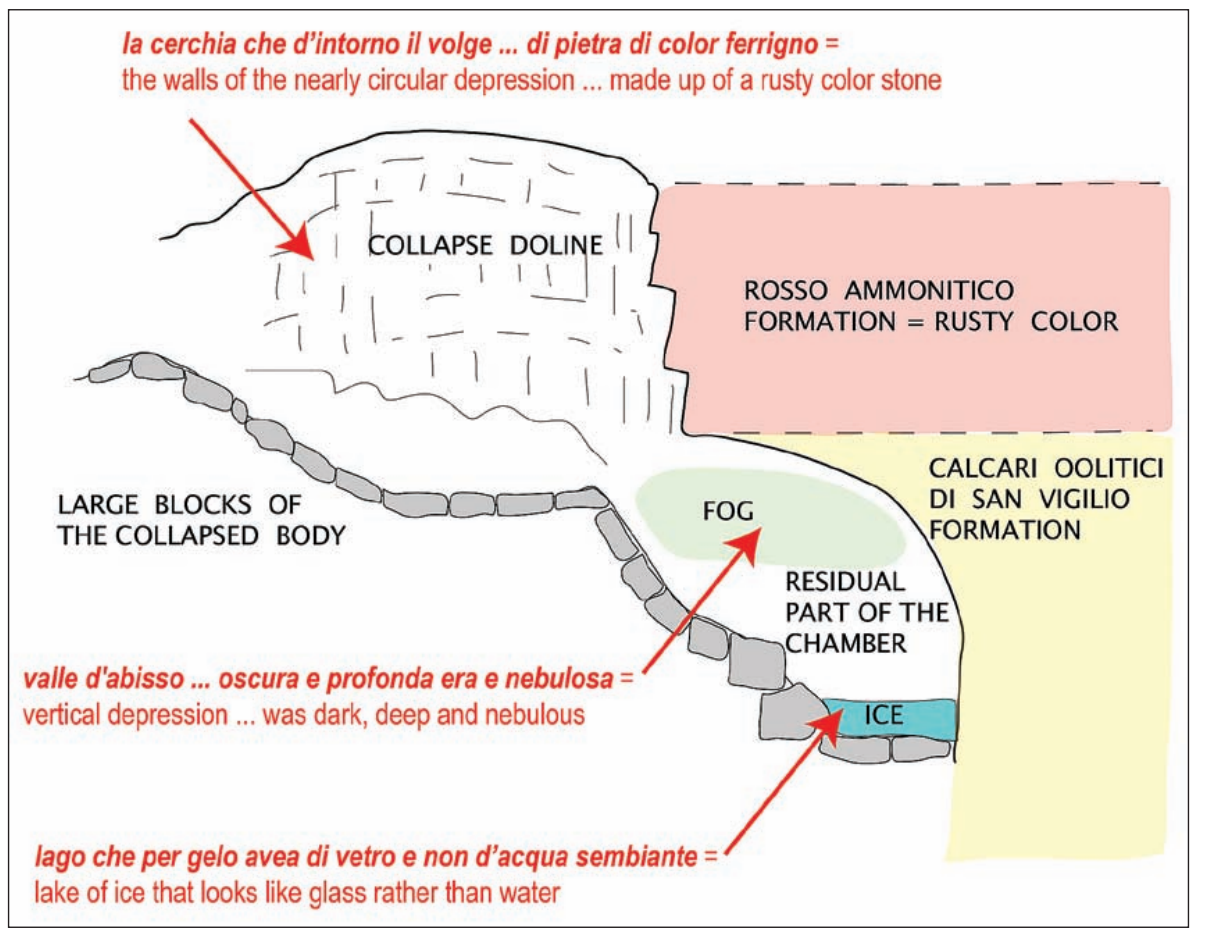

Fig. 3: Sketch showing the main concordances between the characters of the Covolo of Camposilvano and the description of hell made by Dante Alighieri in the Divine Comedy.

Perhaps Dante also visited the entrance to Spluga della Preta, a very deep karst shaft open on the Corno d'Aquilio in the western part of the upper plateau of Lessini. Based on the geomorphological characteristics, it is a reasonable hypothesis that the opening (exposure) of the top of the cavity is quite recent. The entrance could have formed as a consequence of the Verona Earthquake of 1117 that destroyed most of the large churches of the region and produced specific forms in the mountains,

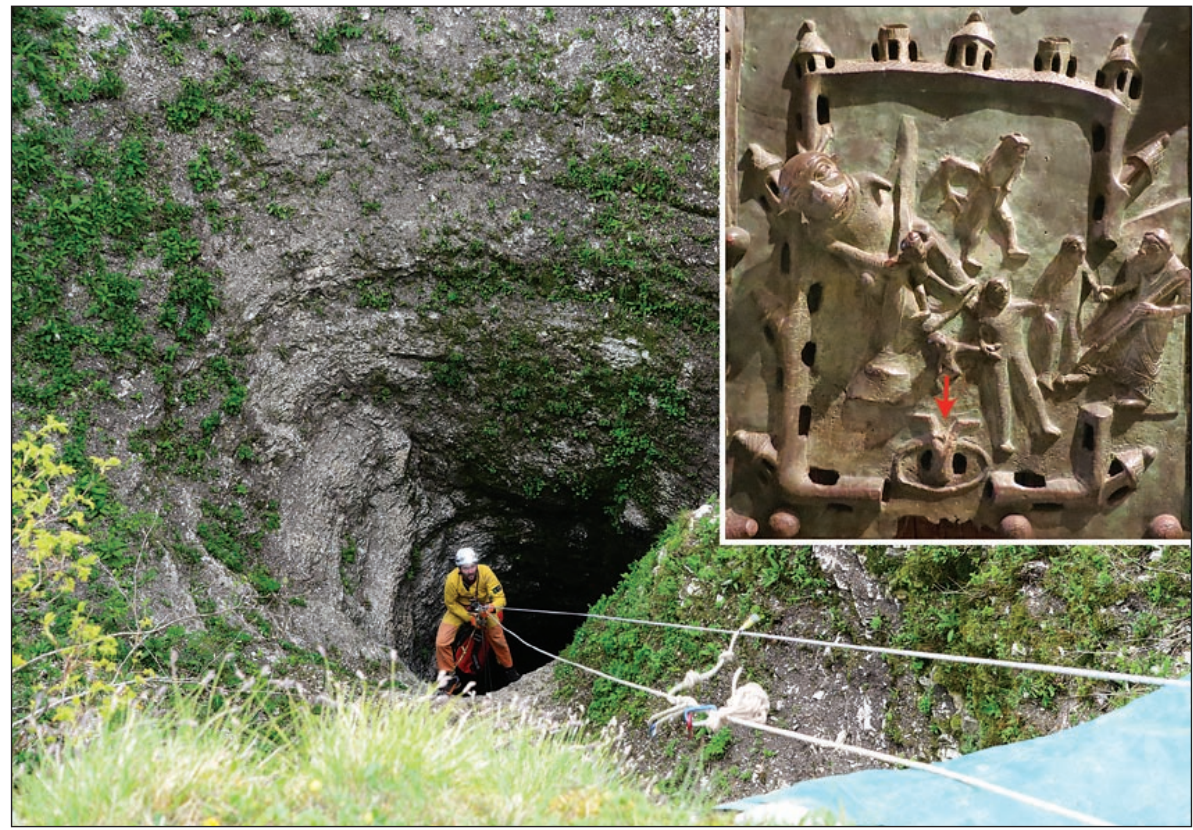

as surface faulting, large landslides and karst collapses (Sauro 2010; Sauro \& Ferrarese 2016). At that time such abruptly opened cavities were considered the entrances to Hell, as represented in a bronze panel in the old door of San Zeno Church in Verona, partly rebuilt a few decades after that famous earthquake and certainly known by Dante (Fig. 4).
Fig. 4: The entrance to the Spluga della Preta, which probably opened during the earthquake of Verona in 1117, and a bronze panel of the door of the church of San Zeno in Verona. It is possible to recognize the devil throwing people into the cavity of hell, the entrance of which seems to be inspired by a karstic well (Photo: $U$. Sauro). 


\section{ANDREA MANTEGNA}

In the Ducal Palace of Mantua, on the walls of the socalled Camera degli Sposi (Room of the Spouses), there is a painting created during the XV. century (1474) by the famous painter Andrea Mantegna. It includes, in a fantasy landscape context, a representation of a natural limestone arch that recalls the Lessini 'natural bridge' known as the Ponte di Veja (Mietto \& Sauro 2000). This arch was part of the roof of a very large cave, collapsed in its inner parts to form a karst window where a creek and the entrances of several caves can be seen (Fig. 5).

It is reasonable to suppose that at the time the courts of noble families organized special excursions to visit not only the nearby towns but also natural curiosities, and Andrea Mantegna probably took part in an excursion to Ponte di Veja.

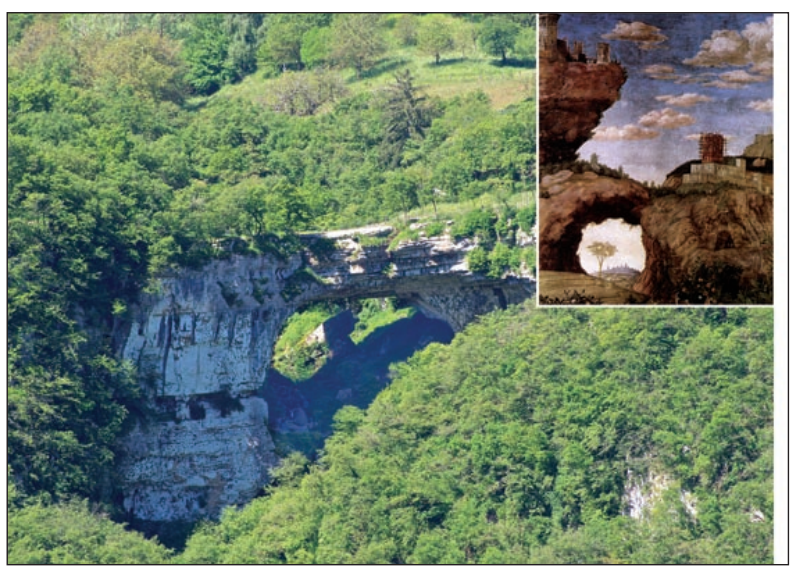

Fig. 5: The Ponte di Veja is the entrance to a great cavern the vault of which is partially collapsed. The painter Andrea Mantegna has portrayed it in fantastic scenery in the Camera degli Sposi of the Palazzo Ducale in Mantua (Photo: U. Sauro).

\section{CULTURAL LEADERS OF THE RENAISSANCE AND MODERN TIMES}

Here we describe a few among the many actors. In Verona during the XVI. century (1571), the pharmacist Francesco Calceolari created one of the first "Wunderkammer", consisting of an exhibition of curious objects collected for the most part in the Monti Lessini and Monte Baldo mountains. The exhibits included fossils, such as fossil fishes collected at the famous site of Bolca (Vai \& Cavazza 2003; Brugnoli et al. 2009).

The case of Gregorio Piccoli, a priest born in the Lessini Mountains who was involved in cartography and natural sciences, is very interesting. While remaining anchored in traditional beliefs, he applied the criteria of modern science to his hypotheses. Thus, in 1736, after a visit to a cave called La Tanesela, where many bones of ancient animals had been found in the fillings, he published in 1739 a booklet titled: Ragguaglio di una grotta, ove sono molte ossa di Belve diluviane nei Monti Veronesi, e dei Luoghi di quei contorni; e Strati di Pietra, tra i quali stanno i Corni Ammoni; e ove si ritrovano altre Produzioni marittime impietrite, e come in Dissegno si dimostra (Description of a cave, where there are many bones of animals of the Deluge, in the Veronese Mountains, and places nearby; and the layers of stone, among which are ammonites; and where other petrified marine fossils are found, as shown in a drawing) (Piccoli 1739).

So, starting from the assumption that the bones belong to animals, which he calls "diluvial wild beasts", drowned during the great flood and then sucked by the

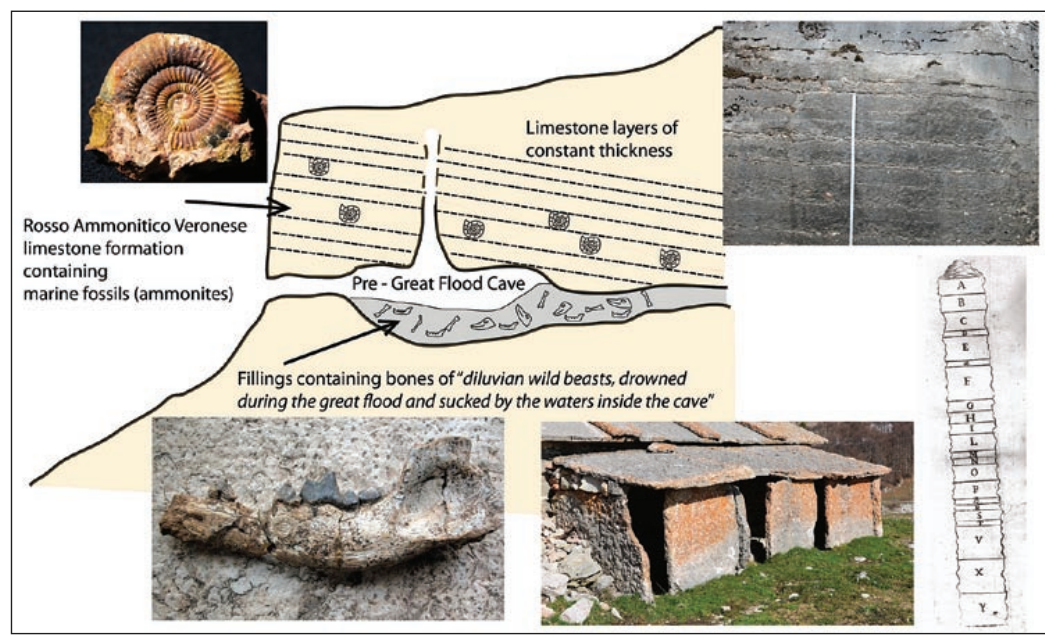

Fig. 6: The priest Don Gregorio Piccoli in 1739 published a book describing a cave full of bones in the Lessini mountains. He supposed that the bones belonged to "wild beasts" drowned during the universal flood and then sucked by the waters into the cave, which formed into a rock containing marine fossils, such as the ammonites (called: ammonite horns). Therefore, the cave had already existed at the time of the great flood and the rocks in which the cave was formed are older than the flood, and were deposited on the bottom of an ancient sea. Observing that the layers containing ammonites have an almost constant thickness across the area, he suggested that the bottom of that ancient sea was roughly flat, and therefore the mountains had not existed then (Photos: U. Sauro). 


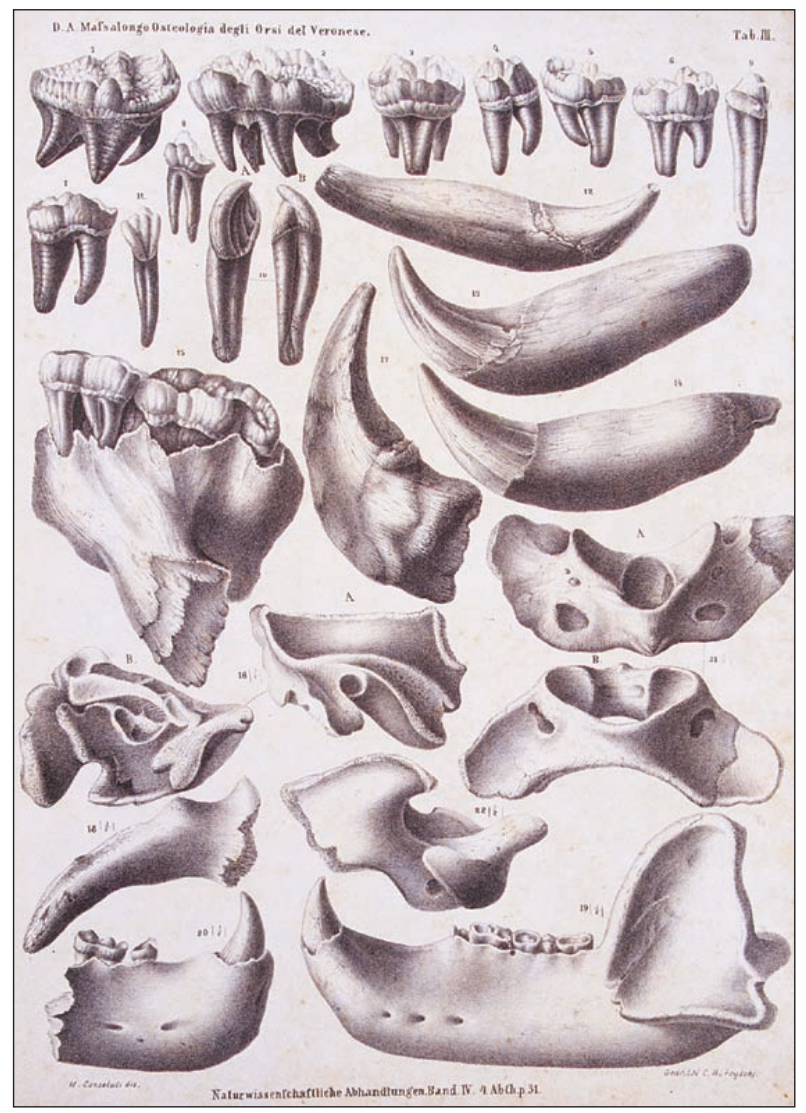

Fig. 7: Table in the publication of Abramo Massalongo regarding the bones of cave bears collected in the Covoli of Velo (Massalongo 1851).

waters inside the cave, he finds that the cave was formed in a rock containing marine fossils, including the ammonites (Ammon horns). Consequently the cave must have existed at the time of the great flood, and the rocks where the cave was formed, which contain marine fossils, are more ancient than the Flood. He therefore finds that, once, in place of the mountains there was a sea. Observing, moreover, that the layers containing the ammonites are of nearly constant thickness throughout the area, he deduces that the bottom of the ancient sea was approximately horizontal and that there were still no mountains. However, he concludes that it is perfectly clear how complex the problem is to reconcile the data in one satisfactory model, given the "fixed" as- sumption of the Biblical Flood (Fig. 6). Then he writes: Vero verissimo tutto ciò, come abbiamo esposto, siamo tra diverse verità, che l'una con l'altra per solo benefizio di naturali leggi se non è impossibile, difficilissimo sarà a concordarle ...(All this is true, and it is clear that we are between different truths, which, on the basis of the natural laws only, it is very difficult if not nearly impossible to agree ...).

In the second half of the XVIII. century, some nobles of Verona collected the bones of large mammals discovered in the fillings of a karst cave called the fillings of a karst cave called Grotta della Vacca Marina (Sea Cow Cave). The sizes of the bones were comparable with those of a whale (Fortis 1786). In reality the huge bones belonged to ancient elephants (Elephas antiquus) and other large mammals (Rhinos sp.). Many of these bones were later seized by scholars following in the wake of the Napoleonic army and ended up in the Museum of Paris. A few are preserved in the Natural History Museum of Verona.

The cave complex of the Covoli di Velo, consisting of several natural passages filled with bones of Pleistocene vertebrates (especially of Ursus Spelaeus) has been the object of research for many scholars (Benetti \& Sauro 2000; Sauro 2000). The abbot, Alberto Fortis (Fortis 1785-1786), believed that the bones inside those cavities were remnants of "amphibia", similar to seals, that lived here during the Diluvial period. A few years later, the naturalist Giovanni Serafino Volta (Volta 1796-1809) demolished the opinions of Fortis, demonstrating that the bones belonged to large land mammals.

In the first half of 1800 s the naturalist Abramo Massalongo, who lived in the valley of Illasi not far from the Covoli di Velo, witnessed the passage of carts full of the bones of these ancient animals, that had been dug out of the caves to be used as fertilizers. He bought the loads of some of the carts and studied the bones, showing that they belonged mostly to cave bears. In 1851 he published a paper in a series by the Museum of Natural History of Vienna (Massalongo 1851; Fig. 7). For his paleontological research Massalongo is regarded as one of the founders of the science of paleobotany.

These are only some of the many stories that bind scholars and the curious to the karst heritage of Monti Lessini.

\section{THE KARST ENVIRONMENT AND THE INHABITANTS OF THE MOUNTAINS}

Besides the speculations of cultured men, it is interesting to consider how the karst has been perceived by the inhabitants of the mountains, who were mostly farmers and loggers (Pasa 1954; Sauro 1993, 2006). 
These inhabitants appreciated that, although there were consistent amounts of precipitation, there was no surface water except for a few small springs, so they had to face the problem of constructing water reservoirs, a prerequisite to living in such a karstic environment. Like the inhabitants of other karst regions, they chose to store rainfall water flowing from the stone roof slabs of their houses in earthen cylindrical cisterns called possi, which were made by building two concentric cylindrical walls and filling the void between them with clayey soil (Sauro 2006). Roof water from the houses and cattle sheds was conducted to the cisterns via small wooden channels. Drinking water for animals were supplied by small artificial lakes, posse, obtained by making a closed depression by building earth dams and berms, and waterproofing the bottom with clayey sediments.

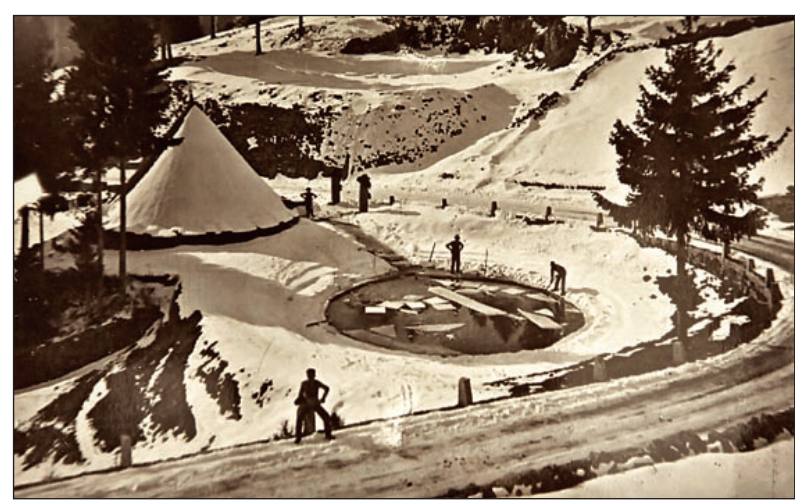

Fig. 8: Production of ice slabs obtained by the naturally frozen water small artificial lakes, then to be kept in cylindrical storehouses that were probably inspired by karst pits. The photo was taken around 1950 (Photo: unknown author).

The people also understood that the water absorbed by the rocks was able to travel a long way following subterranean paths. During the so-called "filò", meetings of the inhabitants of the local small settlements called contrade, held during the winter evenings in the relative warmth of the cattle shed, it was not unusual that a farmer would tell a story about cattle that had fallen into a spluga (karst shaft) had appeared after some time in the big springs at Montorio (the springs of the base level aquifer of Monti Lessini, near Verona); and another farmer might have insisted that in the past a sheep fallen into another karst pit was found later in the lagoon of Venice.

About 50 years ago an old farmer told me he had realized that the water was able to dissolve the limestone rock; starting with such a statement, he explained the presence of the ammonites (locally considered as old petrified snails, or petrified snakes, or as strange jokes of nature: lusus naturae) as a result of the solution of the rock by water. According to his opinion, the water pene- trates into the fissures following concentric paths; so the ribs between the different coils, when present, could be explained as the result of the "losses" of water from one coil to an inner coil.

By contact with the karst environment, local people understood that some karst cavities functioned as natural refrigerators and utilized them to preserve foods such as milk, cheese, butter, and meat. At the entrance to the large collapse pit of the Covolo di Camposilvano, a wall and a door were built to protect the stored foods from animals and thieves.

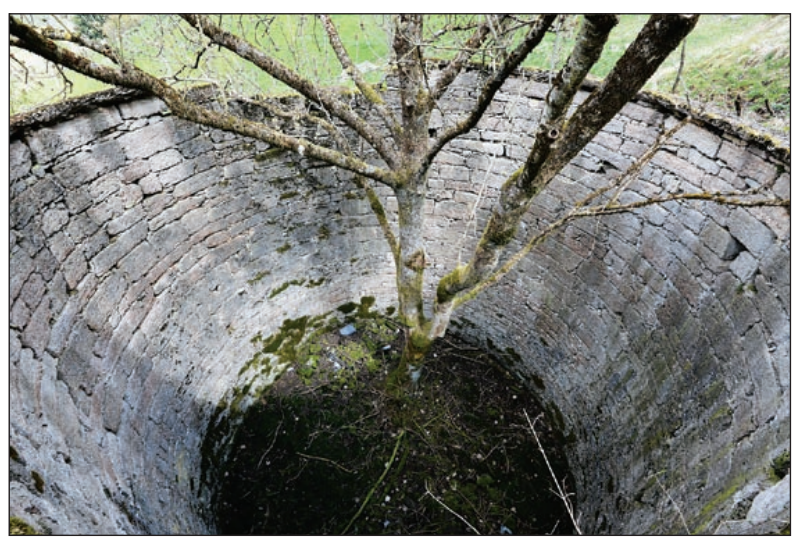

Fig. 9: The cylindrical shaft of an ice storehouse, called "ghiacciaia" or "giassara", which was once covered with a conical roof of reeds (Photo: U. Sauro).

During the Middle Ages, the access to some of these cavities was governed by special rules set out in documents called: Jurisdictio covoli (i.e. Latin expression meaning: law ruling the use of the cavity).

Observing such cold cavities, local people understood that the snow and ice present inside were responsible for the low temperatures. In some cases, the cavities were acting as traps for snow transported by winds during winter storms. So in springtime, some people reaching the high pastures would contribute to the snow fillings by transporting other snow and dumping it into some of the cavities. Later, people constructed some nearly cylindrical or conical artificial cavities, so obtaining the so-called "nivere" in the sense of cavities containing snow, where they stored the snow to be used during the summer in the baiti (small dairies) where milk was transformed into butter and cheese. A further evolution was the production of ice, created during the winter by the natural freezing of artificial pond water and then storing slabs of this ice in special storehouses: large cylindrical containers mostly earthen, called giassare (Figs. 8, 9). During summer, slabs would be taken out in the evening and transported through the night to the towns of the plain, where the ice was sold. 


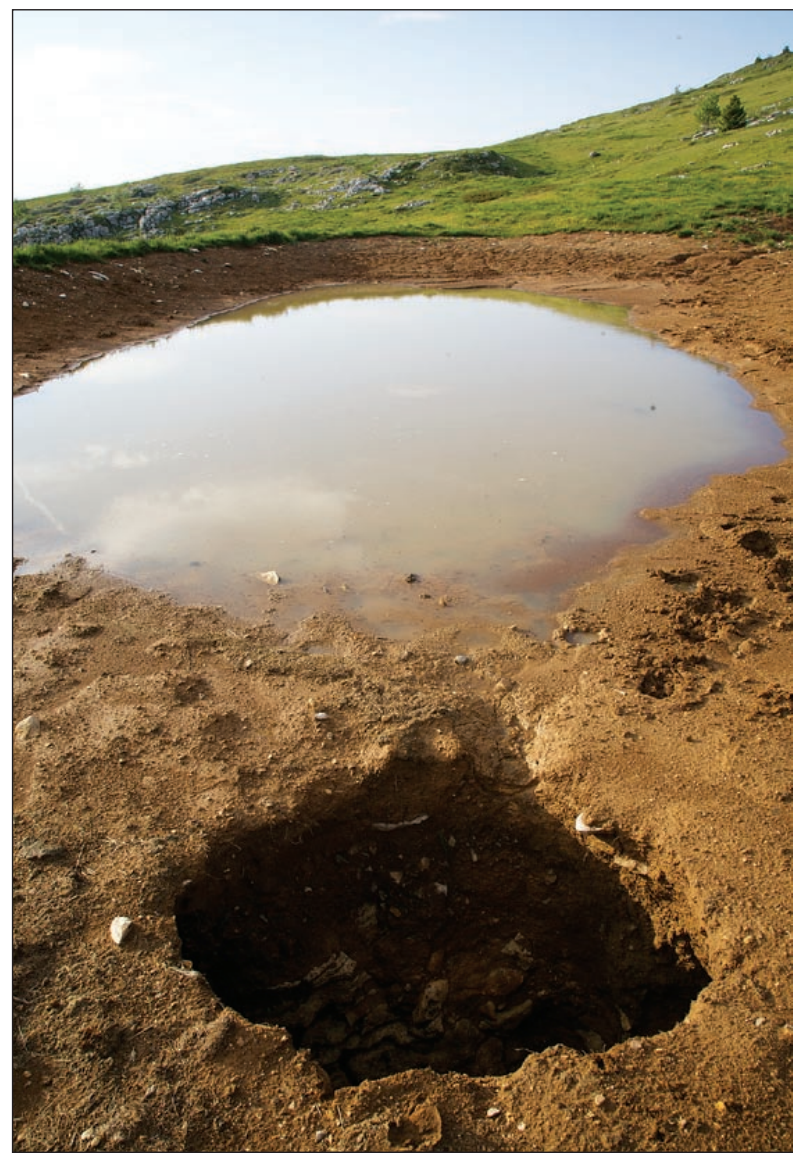

Fig. 10: An artificial pond for watering cows. The bottom waterproofed with clay was perforated by a bubble of air expelled from the epikarst. The expulsion of air caused the opening of a small shaft, with a consequent outflow of water towards underground cavities (Photo: U. Sauro).
Perceiving the dynamics of the karst during and after very strong and concentrated rainfalls is very interesting: in some areas, local people in close contact with nature such as shepherds, heard low frequency sounds coming out from the soil (Sauro et al. 2013). Those people understood that below the soil, there must be inaccessible cavities in the rock mass that they termed "sordie", to distinguish them from the splughe (term deriving from the Latin: spelunca, i.e. the accessible karst cavities open to the surface $=$ caves). By using the term sordie, people were defining these underground, inaccessible karst cavities able to produce sounds in particular situations as distinct musical instruments, 'deaf organs' (i.e. producer of low-frequency sounds - "deaf" may be translated in Italian with sordo, because these sounds are not audible to the hard of hearing; the roaring of expelled air has often been likened to the low pipes on a pipe organ).

Clearly, such sounds are the result of the expulsion of "bubbles" of air trapped in the cavities of the epikarst during heavy rains, when water tends to saturate the voids and isolate bubbles of air which search for ways to escape the pressure exerted by the water.

Sometimes, such bubbles would perforate the clayey bottom of an artificial pond and in this case, the water would form a vortex and be swallowed in a few minutes (Fig. 10). However, the local people designed a system to reduce the risk of perforation of the clay seals. Such a system, sfiato de le sordie, consisted of a special structure installed under the watertight that allowed the air bubbles to come out at the surface through an opening in one side of the basin.

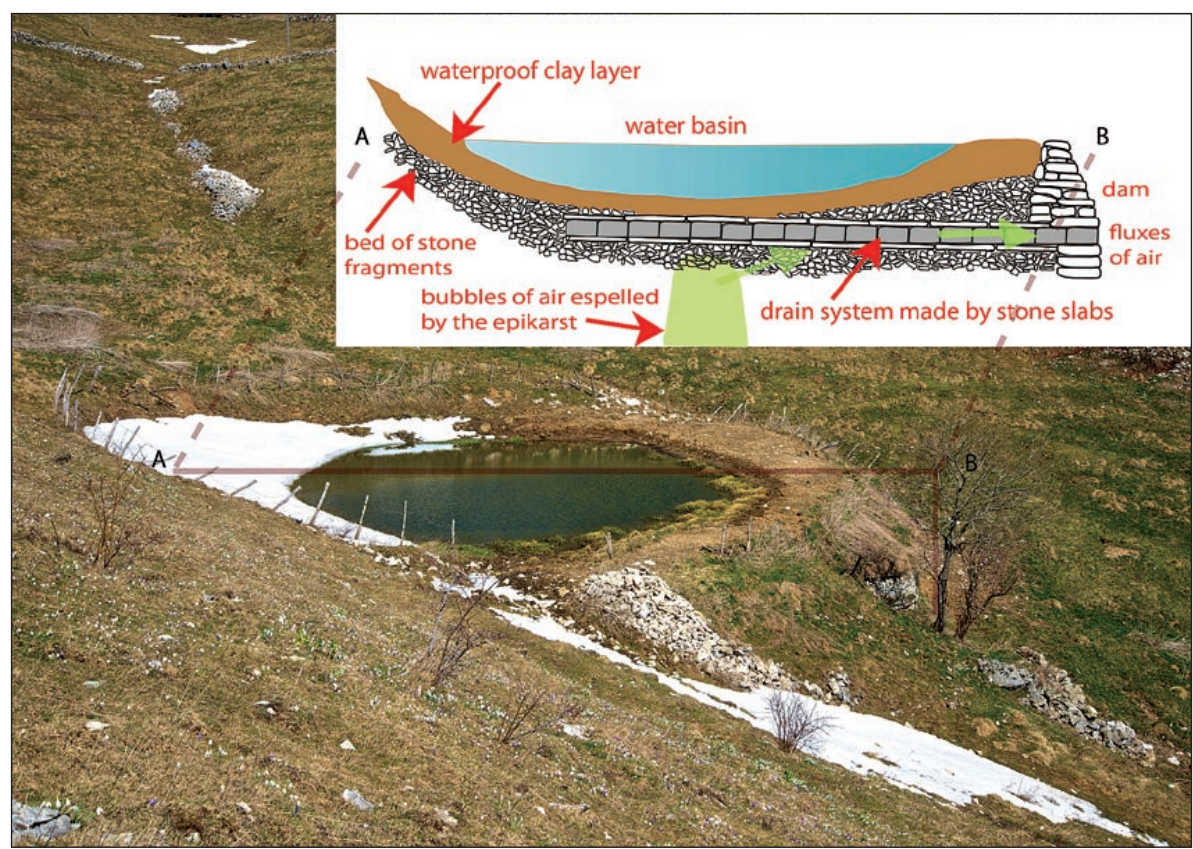

Fig. 11: Section of an artificial pond (pozza) showing the structure of the so-called sfiato delle sordie, conceived and built by man for the lateral drainage of air bubbles expelled from the epikarst. In this way, the risk is reduced that an air bubble pierces the layer of clay waterproofing the bottom of the basin (Photo: U. Sauro). 
The sfiato is made of a thick lens of rock fragments from stone clearance on pastures, which was accumulated at the bottom of an artificial depression closed by building an earth dam, sometimes delimited down valley by a drywall. Above the lens of stones a layer of clayey soil sediments was spread. The lens of rock fragments has a high porosity and contains a drainage system made up of stone slabs, which is open on one side of the embankment. In this way any air bubble escaping from the epikarstic zone under the pond firstly expands in the "pores" of the lens of stones, and then finds an outlet through the drainage system (Fig. 11).
In ponds made more recently, a less efficient sfiato delle sordie discharge system has been achieved, simply by fitting a concrete or plastic pipe arranged vertically, with its lower opening below the waterproof layer and the upper above the water level.

It is therefore evident that the local people of the mountains have been able to understand the dynamics of the epikarst long before the karst researchers. In general, the mountain dwellers of the past knew the environment in which they lived very well and were able to carry out projects using the natural resources and solving a wide range of the problems that they encountered.

\section{ACKNOWLEDGEMENT}

The Author wishes to thank prof. Derek Ford for the very precise editing of the English text and the useful sugges- tions, and two Anonymous Referees for helpful comments.

\section{REFERENCES}

Benetti, A. \& F. Sauro, 2000: Storia delle ricerche sul complesso carsico dei Covoli di Velo.- In: Atti Tavola Rotonda "Un importante sistema carsico dei Monti Lessini (VR): i Covoli di Velo", $16^{\text {th }}-17^{\text {th }}$ April 1999, Camposilvano. Museo Civico di Storia Naturale Verona, 5-12, Verona.

Benetti, A. \& L. Ragnolini, 2008: Nel Covolo di Camposilvano in compagnia di Dante Alighieri.- In: Sauro, U. (ed.) La Lessinia. Ieri, oggi, domani. Quaderno culturale. Vol. 31. Editrice La Grafica, pp. 185-192, Verona.

Brugnoli, A., Latella, L. \& R. Salmaso, 2009: Francesco Calzolari nel contesto del naturalismo europeo del '500.- In: Atti del XVII Congresso ANMS "Al di là delle Alpi e del Mediterraneo", $4^{\text {th }}-7^{\text {th }}$ December 2007, Verona. Museologia Scientifica, 49-52, Verona.

Fortis, A., 1785-1786: Extrait d'une lettre de M. l'abbé Fortis datée de Vérone le 24 Septembre 1785 à M. le Comte de Cassini de l'Académie des Sciences sur différentes pétrifications.- J. Phys., 28/I, 161-168.

Fortis, A., 1786: Delle ossa d'elefanti e d'altre curiosità Naturali de' monti di Romagnano nel Veronese.Vicenza. Turra, pp. 85.
Massalongo, O., 1851: Osteologia degli Orsi fossili nel Veronese, con un saggio sopra le principali caverne del Distretto di Tregnago.- Naturwissensaftliche Abhandlungen, IV, pp. 58, Wien.

Mietto, P. \& U. Sauro, 2000: Le Grotte del Veneto: paesaggi carsici e grotte del Veneto.- Regione Veneto \& La Grafica Editrice, pp. 480, Vago di Lavagno, Verona.

Pasa, A., 1954: Carsismo e idrografia carsica nel Gruppo del Monte Baldo e nei Lessini Veronesi.- Tip. Mareggiani, pp. 150, Bologna.

Piccoli, G., 1739: Ragguaglio di una grotta, ove sono molte ossa di Belve diluviane nei Monti Veronesi, e dei Luoghi di quei contorni; e Strati di Pietra, tra i quali stanno i Corni Ammoni; e ove si ritrovano altre Produzioni marittime impietrite, e come in Dissegno si dimostra.- Stamperia dei Fratelli Merlo, pp. 42, Verona.

Sauro, U., 1973: Il Paesaggio degli alti Lessini: Studio geomorfologico.- Mem. fuori serie, 6, Museo di Storia Naturale di Verona, pp. 160, Verona.

Sauro, U., 1993: Human impact on the karst of the Venetian Fore-Alps, Italy.- Environmental Geology 21, 3, 115-121. DOI: https://doi.org/10.1007/ BF00775294. 
Sauro, U., 2000: Le cavita' carsiche come contenitori di materiali di interesse paleo-ambientale (The karst cavities as containers of materials of paleo-environmental significance).- In: Atti Tavola Rotonda "Un importante sistema carsico dei Monti Lessini (VR): i Covoli di Velo", $16^{\text {th }}-17^{\text {th }}$ April 1999, Camposilvano. Museo Civico di Storia Naturale Verona, 35-44, Verona.

Sauro, U., 2006: Changes in the use of natural resources and human impact in the karst environment of the Venetian Prealps (Italy).- Acta Carsologica, 35, 2, 57-63. DOI: https://dx.doi.org/10.3986/ac.v35i23.228 .

Sauro, U., 2010: Lessinia - montagna teatro e montagna laboratorio.- Cierre edizioni, pp. 280, Verona.
Sauro U. \& Ferrarese F., 2016: Montagne in evoluzione e terremoti: alcuni casi nelle Prealpi Venete, Trentine e Gardesane.- Museo di Storia Naturale e Archeologia, pp. 100, Montebelluna.

Sauro, U., Migliavacca, M., Pavan, V., Saggioro, F., \& D. Azzetti (eds.), 2013: Tracce di antichi pastori negli alti Lessini.- Editrice La Grafica, pp. 368, Verona.

Vai, G.B. \& W. Cavazza (eds.), 2003: Four centuries of the word geology - Quadricentenario della parola geologia. Ulisse Aldrovandi 1603 in Bologna.- Minerva Edizioni, pp. 328, Bologna.

Volta, G.S., 1796-1809: Ittiologia Veronese del Muzeo Bozziano, ora annesso a quello del Conte Giovanbattista Gazzola e di altri gabinetti di fossili veronesi.- Stamperia Giuliari, Verona. 